\title{
Identification of Turnip mosaic virus Isolates Causing Yellow Stripe and Spot on Calla Lily
}

\author{
C. C. Chen, Department of Plant Pathology, Taiwan Agricultural Research Institute, Taiwan; C. H. Chao and C. C. \\ Chen, Taichung District Agricultural Improvement Station, Taiwan; S. D. Yeh, Department of Plant Pathology, Na- \\ tional Chung Hsing University, Taiwan; and H. T. Tsai and C. A. Chang, Department of Plant Pathology, Taiwan \\ Agricultural Research Institute, Wu-Feng, Taichung 413, Taiwan
}

\begin{abstract}
Chen, C. C., Chao, C. H., Chen, C. C., Yeh, S. D., Tsai, H. T., and Chang, C. A. 2003. Identification of Turnip mosaic virus isolates causing yellow stripe and spot on calla lily. Plant Dis. 87:901-905

Two virus cultures, RC4 and YC5, were isolated in Taiwan from calla lily (Zantedeschia spp.) cv. Black magic displaying yellow spot and stripe on leaves. Both isolates were mechanically transmitted to various hybrids of Zantedeschia and induced systemic symptoms similar to those observed on diseased Black magic. In addition to Zantedeschia spp., the two virus isolates also infected several cruciferous species and induced mosaic symptoms. Electron microscopy revealed the presence of flexuous virus particles about $750 \mathrm{~nm}$ in length. The two isolates were propagated in and purified from mustard plants and were used as immunogens for production of antisera in rabbits. In enzyme-linked immunosorbent assay and sodium dodecyl sulfate-immunodiffusion tests, both antisera reacted strongly with their homologous antigens and with antigens of two Turnip mosaic virus (TuMV) isolates from radish (TuMV-R) and lisianthus (TuMVL), but not with 21 other different potyviruses tested. In reciprocal tests, antisera against TuMV$\mathrm{R}$ and TuMV-L also reacted strongly with RC4 and YC5 antigens, indicating that these two calla lily isolates are serologically indistinguishable from other known TuMV strains. Cloning and sequence analyses confirmed that both isolates shared 95 to $99 \%$ of deduced amino acid sequence identities in the coat protein genes with those of various known TuMV strains. This investigation represents the first record of the natural infection of TuMV in calla lily.
\end{abstract}

Additional keywords: capsid protein gene sequence, serological detection, virus identification

Calla lily (Zantedeschia spp.), an aroid plant species indigenous to Africa, is a popular ornamental crop in Taiwan and many other countries. Farm acreage of calla lily in Taiwan has increased in recent years. Virus diseases and bacterial soft rot are the two major factors limiting its production. Among viruses, Dasheen mosaic virus (DsMV), Cucumber mosaic virus, and Tomato spotted wilt virus occur naturally in calla lily (32). In addition to DsMV, three other potyviruses, Konjak mosaic virus (KMV), Bean yellow mosaic virus (BYMV), and an unknown virus associated with symptomatic Zantedeschia plants were identified (21). DsMV is considered the most prevalent and widespread virus in the family Araceae, including Zantedeschia spp. $(29,30,32)$. The virus is found in calla lily in Taiwan and induces mosaic and distortion symptoms on leaves of most commercial cultivars. In 2001, a potyvirus provisionally named Zant-

Corresponding author: C. A. Chang

E-mail: cachang@wufeng.tari.gov.tw

Accepted for publication 28 March 2003.

Publication no. D-2003-0602-03R

(C) 2003 The American Phytopathological Society edeschia mosaic virus (ZaMV) (9) was isolated in Taiwan from calla lily plants bearing symptoms similar to those caused by DsMV. ZaMV later was identified as a strain of KMV (17).

In 2000, we found that some imported calla lily plants exhibited yellow spot and stripe symptoms which were very different from those reported for DsMV and KMV. Tissue extracts of leaf samples collected from these plants reacted slightly with the antibody against DsMV. The extract, however, reacted strongly with the antiserum prepared for Turnip mosaic virus (TuMV), a potyvirus widely distributed in cruciferous plants but never known to infect calla lily $(15,23)$. The biological, serological, and molecular properties of YC5 and RC4 virus cultures isolated from diseased calla lily were compared with those of known strains of TuMV and other potyviruses. Our results indicate that the two isolates are strains of TuMV. This is the first record of infection of TuMV in araceous plants.

\section{MATERIALS AND METHODS}

Virus source and maintenance. Bulbs from diseased calla lily showing yellow spot and stripe symptoms on leaves were collected from Ho-Li Township and the experiment farm of Taiwan Agricultural Research Institute (TARI). Some calla lily plants in the fields, planted from imported bulbs, were about 3 months old and others were 3- to 5-month-old tissue culture-derived seedlings. Diseased bulbs were grown in 18-cm (7-in.) pots under greenhouse conditions for subsequent studies. Chenopodium quinoa Willd., inoculated with the extracts of diseased plants, developed local lesions 7 days after inoculation. Single lesions were isolated and re-inoculated on healthy plants of $C$. quinoa. This process was repeated three times. Two isolates, RC4 (collected from Ho-Li) and YC5 (from TARI), inducing systemic infection in calla lily and mustard (Brassica juncea L.), were established. For subsequent experiments, cultures of YC5 and RC4 were propagated routinely in mustard. For longterm storage, diseased mustard leaves were stored in $50 \%(\mathrm{vol} / \mathrm{vol})$ glycerol at $-20^{\circ} \mathrm{C}$.

Host reaction tests. Reactions of the two isolates on different hosts were conducted by mechanical inoculation. Inocula, 1:10 dilution (wt/vol), were prepared by grinding leaves of infected mustard plants in potassium phosphate buffer $(50 \mathrm{mM}, \mathrm{pH}$ 7.5). At least 20 plants of each species were inoculated and kept in an insect-proof greenhouse for 1 month or longer for observation of symptom development.

Virus purification. Leaves of mustard, 14 days after inoculation, were used for virus purification. Viruses were purified according to the procedures described previously for several potyviruses (11). Yields of virions were determined by absorbance at $260 \mathrm{~nm}$ (HITACHI spectrophotometer 220S; Hitachi, Ltd., Tokyo, Japan) and calculated using an extinction coefficient of 2.4 for potyviruses without light scattering correction (16). The purity and the molecular weight of capsid protein were analyzed by discontinuous sodium dodecyl sulfate-polyacrylamide gel electrophoresis (SDS-PAGE) after treating the purified virions with an equal volume of dissociation buffer $(250 \mathrm{mM}$ Tris- $\mathrm{HCl}$, containing $2 \%(\mathrm{wt} / \mathrm{vol})$ SDS, $4 \%$ (vol/vol) 2-mercaptoethanol, and $10 \%$ (wt/vol) sucrose) as described by Laemmli (18).

Electron microscopy. Virus particles from infected tissue extracts or purified samples were negatively stained with $2 \%$ uranyl acetate $(\mathrm{pH}$ 4.2) as described by Christie et al. (13) and examined with an electron microscope (HITACH H-7000; Hitachi, Ltd.). 
Antiserum preparation and serological tests. Antisera were prepared by immunizing New Zealand white rabbits with purified virus. The immunization protocols were the same as those described $(1,11)$. Immunized rabbits were bled weekly 7 days after the last injection. Serological relationships of YC5 and RC4 with 23 known potyviruses were analyzed by reciprocal SDS-immunodiffusion test and enzyme-linked immunosorbent assay (ELISA). Procedures of SDS-immunodiffusion tests and ELISA were described previously
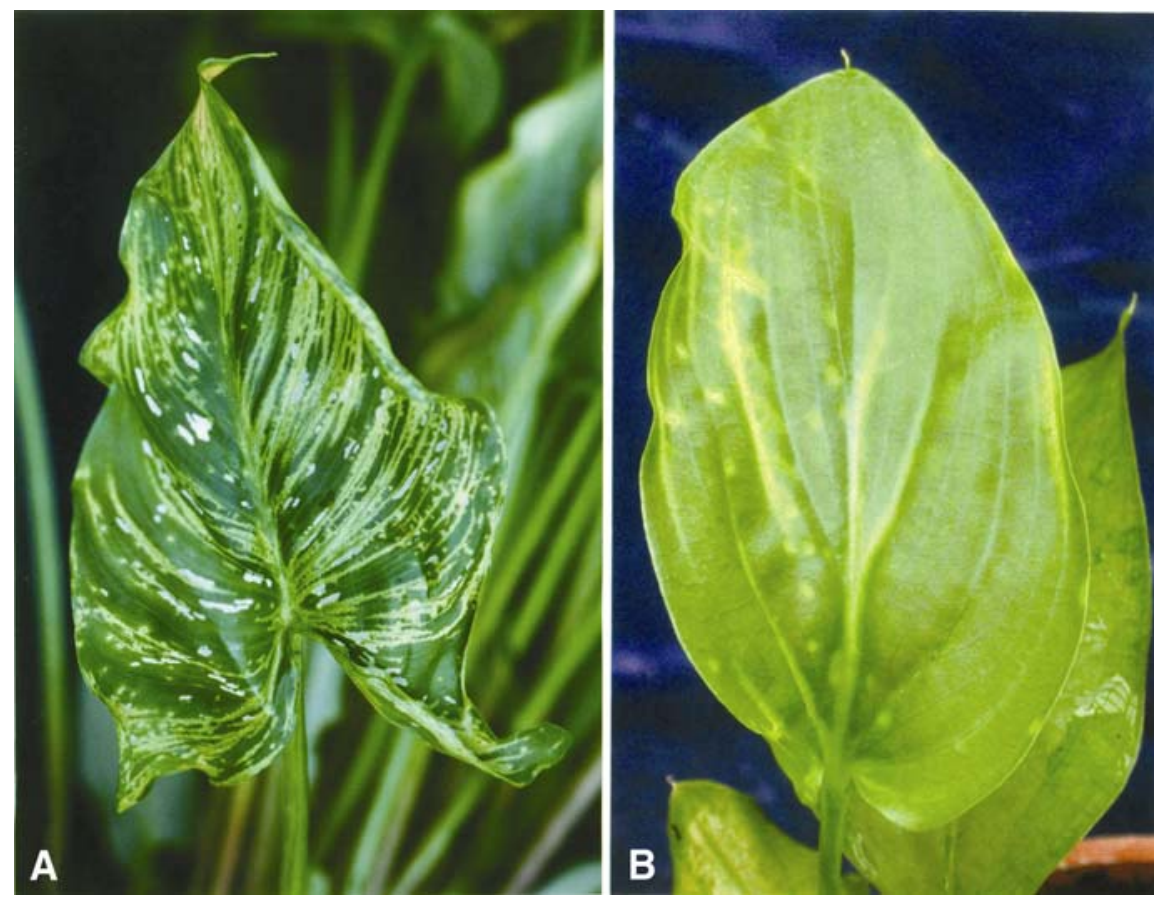

Fig. 1. Symptoms induced by Turnip mosaic virus (TuMV) on calla lily plants. A, Severe yellow spot and stripe symptoms observed on infected calla lilies in the field; $\mathbf{B}$, yellow spot and stripe symptoms on the leaf of tissue cultured seedling after inoculation with TuMV-YC5 isolate.

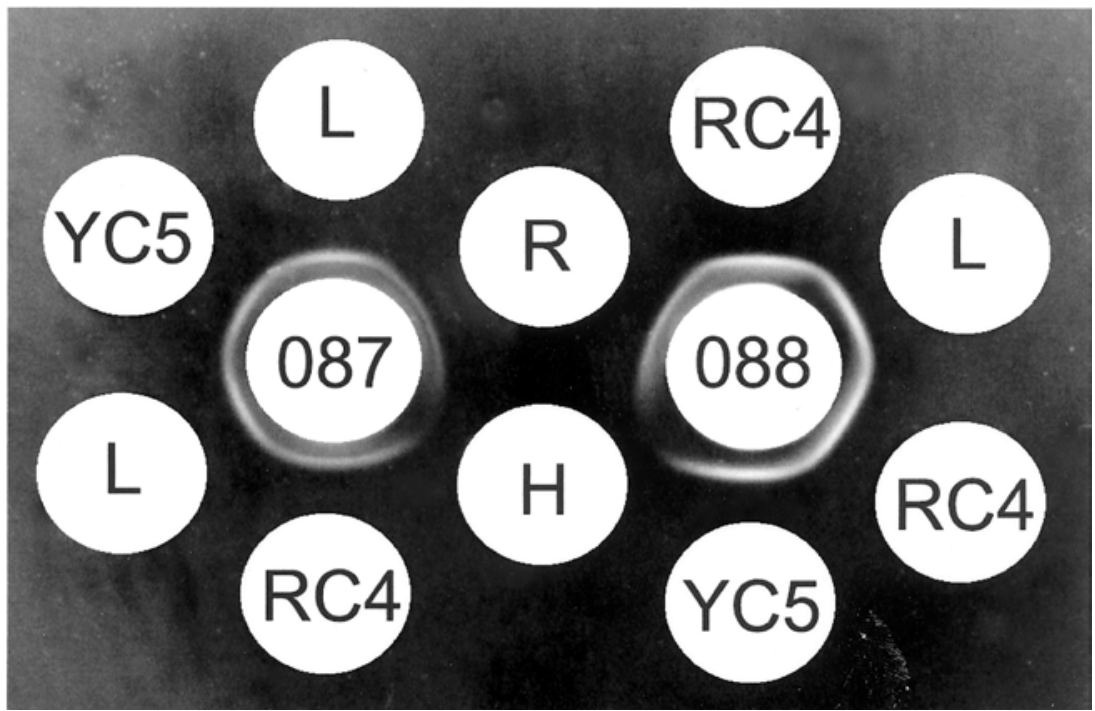

Fig. 2. Serological comparisons between isolates of Turnip mosaic virus (TuMV) obtained from radish (R), lisianthus (L), and calla lily (RC4 and YC5) in sodium dodecyl sulfate (SDS) immunodiffusion tests. The center wells were added with antisera against TuMV-L (\#087) and TuMV-RC4 (\#088), and the peripheral wells were filled with SDS-treated antigens of uninfected mustard (H), TuMV-R (R), TuMV-L (L), RC4, and YC5.
1), Passionfruit woodiness virus (PWV; 1) Ts isolate of Peanut stripe virus (PStV-1; 8), Pea seedborne mosaic virus (PSbMV; 5), Potato virus $Y$ (PVY; 28), Soybean mosaic virus (SMV; 2), Tuberose mild mosaic virus (TMMV; 11), radish and lisianthus isolates of TuMV-R and TuMV$\mathrm{L}$, respectively (10), Watermelon mosaic virus 2 (WMV2; 26), and Zucchini yellow mosaic virus (ZYMV; 24). Antisera against DsMV and KMV used in this study were prepared against bacterial expressed viral coat protein as described previously (12). Commercial immunoglobulins against DsMV were purchased from Agdia, Inc. (Elkhart, IN).

Reverse transcription-polymerase chain reaction and nucleotide sequence analysis. The viral RNA was extracted from the purified virion by the QIAamp Viral RNA Mini kit (Qiagen, Hilden, Germany). The first strand of cDNA was synthesized from the viral RNAs by a cDNA synthesis kit (Stratagene, La Jolla, CA) with the addition of an oligo-dT primer. Subsequently, one set of primers designed by Pappu et al. (20) was used to amplify the $3^{\prime}$ terminal regions of YC5 and RC4 RNAs via polymerase chain reaction (PCR). The exTaq polymerase (TaKaRa, Shuzo Co., Shiga, Japan) was used for the PCR amplification for 25 cycles (GeneAmp system 2400; Perkin-Elmer, Norwalk, $\mathrm{CT}$ ) using the following program: denaturing at $94^{\circ} \mathrm{C}$ for $1 \mathrm{~min}$, annealing at $51^{\circ} \mathrm{C}$ for $30 \mathrm{~s}$, and DNA synthesis at $72^{\circ} \mathrm{C}$ for 2 min. For amplification of $\mathrm{RC} 4$, all reaction steps and conditions were the same as those for YC5, except that annealing was done at $45^{\circ} \mathrm{C}$ for $50 \mathrm{~s}$. An elongation step at $72^{\circ} \mathrm{C}$ for 6 min was conducted at the last cycle for both isolates. Amplified products were analyzed by electrophoresis in a $1.2 \%$ agarose gel and subsequently cloned into a pCRII-TOPO vector (Invitrogen, Carlsbad, CA) according to manufacturer's instruction. Plasmid clones with expected DNA inserts were selected for sequence analyses. Sequencing of the target DNA was done by an automatic DNA sequencer (ABI PRISM 377; Perkin-Elmer, Applied Biosystems Division) with the BigDye Terminator Cycle Sequencing Ready Reaction Kit (Perkin-Elmer). Nucleotide sequence of each virus isolate was determined from three to four independent clones. Sequence data was analyzed and compared with those of known potyvirus species by the program of Vector NTI Suite (InforMax, Inc., Bethesda, MD).

\section{RESULTS}

Host reaction and symptomatology. Field surveys of a calla lily plantation in 2000 revealed that some plants showed yellow spot and stripe symptoms on leaves (Fig. 1A). They were different from the mosaic symptoms induced by DsMV and KMV. Tissue extracts of the diseased plants reacted slightly with DsMV antibod- 
ies in indirect ELISA tests; however, the ELISA readings were just barely above the threshold (two times of absorbance at 405 $\mathrm{nm})$ of the control antigens of uninfected healthy plants (data not shown). However, the extracts of the diseased samples reacted strongly with antibodies against TuMV, indicating that TuMV might be the causal agent of the disease. None of the 21 other potyvirus antisera reacted with the diseased plant extracts.

The two isolates YC5 and RC4, obtained by single lesion isolation, induced typical yellow spot and stripe symptoms on calla lily cv. Black Magic (Fig. 1B). They also induced systemic mosaic symptoms on leaves of various cruciferous plants including Brassica juncea, B. oleracea var. botrytis, B. oleracea var. capitata, and Raphanus sativas. None of the same cruciferous plant species were infected when inoculated with DsMV isolates from our collection. When either YC5 or RC4 was inoculated on tissue-culture derived calla lily seedlings, yellow spots appeared on the inoculated leaves 3 to 5 days after inoculation. Yellow stripes scattered with spots gradually developed on newly emerged noninoculated leaves (Fig. 1B). These symptoms were similar to those observed in the field. When two TuMV isolates, L and $\mathrm{R}$, isolated from lisianthus and radish (10), respectively, were used for inoculation, similar yellow spot and stripe symptoms were developed on leaves of inoculated calla lily plants.

Virus purification. Both YC5 and RC4 isolates were individually propagated in mustard plants and purified by differential and cesium sulfate equilibrium centrifugations. Purified virion preparations had a UV absorption spectrum and 260:280 absorption ratio of 1.24 , typical of potyviruses (28). The estimated yields of purified
YC5 and RC4 were 2 and $3 \mathrm{mg}$ per $100 \mathrm{~g}$ of tissue, respectively. The estimated molecular mass of coat protein in $12 \%$ polyacrylamide gel was $37 \mathrm{kDa}$ (PAGE, data not shown), similar to that reported for other TuMV isolates $(10,23)$.

Electron microscopy. Flexuous rodshaped virus particles about $750 \mathrm{~nm}$ in length were observed in negatively stained infected tissue extracts and purified virion preparations of the two calla lily isolates.

Serology. Polyclonal antisera \#088 and \#091 were prepared against the purified virions of isolates RC4 and YC5, respectively. RC4 antiserum reacted strongly in SDS-immunodiffusion tests with its homologous antigen as well as with YC5, TuMV-L, and TuMV-R (10) (Fig. 2). Similar results were obtained for YC5 antiserum with TuMV-L, TuMV-R, and RC4 (data not shown). In a separate test using
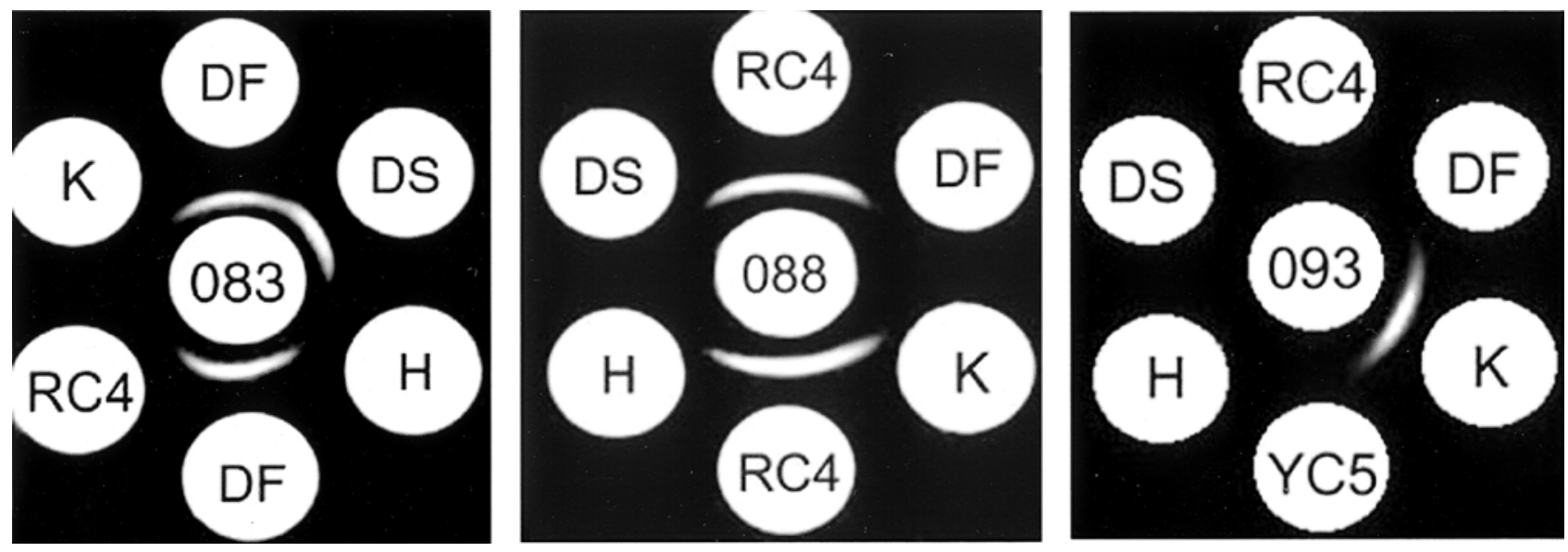

Fig. 3. Serological comparisons among Turnip mosaic virus (TuMV), Dasheen mosaic virus (DsMV), and Konjak mosaic virus (KMV) in sodium dodecyl sulfate (SDS) immunodiffusion tests. The antisera against TuMV-RC4 (\#088), DsMV (\#083), and KMV (\#093) were applied in central wells. SDS-treated antigens of TuMV-RC4 and YC5, an isolate of DsMV (DS) from Taiwan, DsMV-DF from Florida (gift of Dr. F. W. Zettler), and KMV-R7 (K) obtained from calla lily plants in Taiwan were placed in peripheral wells.

Table 1. Reactions of antisera against Turnip mosaic virus (TuMV), Konjak mosaic virus (KMV), and Dasheen mosaic virus (DsMV) with their antigens as determined by direct (D) and indirect (In) enzyme-linked immunosorbent assay (ELISA) ${ }^{\mathrm{a}}$

\begin{tabular}{|c|c|c|c|c|c|c|c|}
\hline \multirow[b]{3}{*}{ Antigens $^{c}$} & \multicolumn{7}{|c|}{ Antisera against three different potyviruses infecting calla lilies ${ }^{b}$} \\
\hline & \multicolumn{2}{|c|}{ TuMV } & \multicolumn{2}{|c|}{ KMV } & \multicolumn{2}{|c|}{ DsMV } & \multirow{2}{*}{$\begin{array}{c}\text { DsMV-Agdia } \\
\text { In }\end{array}$} \\
\hline & In & $\mathbf{D}$ & In & D & In & D & \\
\hline TuMV-YC5 & 2.66 & 0.89 & 0.24 & $\underline{0.01}$ & 0.39 & $\underline{0.15}$ & 0.56 \\
\hline TuMV-RC4 & 2.38 & 0.39 & 0.18 & $\overline{0.02}$ & 0.40 & $\overline{0.03}$ & 0.54 \\
\hline TuMV-L & 2.27 & 0.42 & 0.28 & $\overline{0.00}$ & 0.37 & $\overline{0.06}$ & 0.83 \\
\hline TuMV-R & 2.14 & 0.40 & 0.36 & 0.03 & 0.38 & 0.05 & 0.54 \\
\hline Mustard (CK) & 0.13 & 0.09 & 0.08 & $\overline{0.03}$ & 0.14 & $\overline{0.10}$ & 0.13 \\
\hline KMV-R7 & $\underline{0.11}$ & $\underline{0.00}$ & 1.38 & $\underline{0.06}$ & $\underline{0.09}$ & $\underline{0.02}$ & 0.52 \\
\hline KMV-M7 & $\overline{0.02}$ & $\overline{0.01}$ & 1.35 & $\overline{0.16}$ & $\overline{0.14}$ & $\overline{0.01}$ & $\underline{0.17}$ \\
\hline DsMV-S & $\underline{0.16}$ & $\underline{0.03}$ & $\underline{0.10}$ & $\underline{0.04}$ & 2.99 & 0.90 & 2.44 \\
\hline DsMV-L23 & $\overline{0.04}$ & $\overline{0.01}$ & $\overline{0.19}$ & $\overline{0.12}$ & 3.36 & 0.87 & 3.04 \\
\hline Call lily (CK) & $\overline{0.10}$ & $\overline{0.02}$ & $\overline{0.11}$ & $\overline{0.09}$ & 0.11 & 0.09 & 0.13 \\
\hline
\end{tabular}

${ }^{a}$ D- and In-ELISA described previously (11) were used to determine the serological relatedness among three potyviruses infecting calla lily. Purified immunoglobulins were diluted to 1:1000, and the antigens to $1 / 100$.

${ }^{b}$ The antisera DsMV-Agdia was purchased from Agdia Inc. (Elkhart, IN) and the other three were produced in our laboratory. Antiserum to TuMV was prepared against intact virions purified from TuMV-YC5-infected mustard tissue, whereas antisera to KMV and DsMV were both against purified bacterium expressed coat protein. Reactivities are shown as absorbance at $405 \mathrm{~nm}\left(A_{405 \mathrm{~nm}}\right)$, with readings taken 40 min after addition of enzyme substrate solution. The absorbance values are an average of two replicate wells. Readings lower than two times the control $A_{405 \mathrm{~nm}}$ are determined as negative reactions and are underlined.

c Antigens of TuMV isolates (YC5, RC4, L, and R) were propagated in mustards, whereas those of KMV (isolates R7, M7, and M11) and DsMV (isolates $\mathrm{S}$ and L23) were obtained from infected calla lily. Noninoculated mustard and calla lily (CK) were used as controls. 
TuMV-RC4, DsMV, and KMV antisera, precipitin lines were observed only in homologous reactions (Fig. 3). Neither antiserum reacted with the following potyviruses: BCMV, BICMV, BYMV-L, BYMV-Scott, CYVV, LiMV-TP1, LPV, LyMMV, PaMV, PCV, PRV-W, PSbMV,

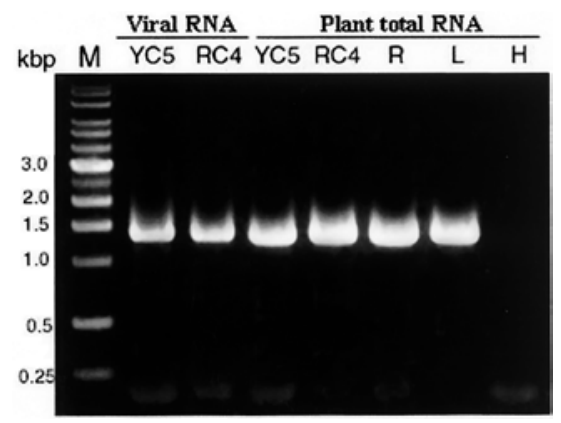

Fig. 4. Agarose gel electrophoresis of DNA products derived from amplification of RNAs of four isolates of Turnip mosaic virus (TuMV) with Potyvirus-specific degenerate primer by reverse transcription-polymerase chain reaction. Purified RNA from virus particles of YC5 and RC4 or total RNAs extracted from infected tissues were used as templates for amplification. Lane M is the molecular markers. Lane $\mathrm{H}$ represents the total RNA purified from uninfected mustard tissue.
PStV-Ts, PVY, PWV, SMV, TMMV, WMV-2, and ZYMV in ELISA and SDSimmunodiffusion tests (data not shown). In reciprocal SDS-immunodiffusion tests with the 23 potyvirus antisera, only the antisera against TuMV-L (\#087) and TuMV-R reacted with both RC4 and YC5 antigens, and the precipitin lines fused with each other without any discernible spur reactions (Figs. 2 and 3; data not shown). The results indicate that the two RC4 and YC5 isolates from calla lily are serologically indistinguishable from TuMV isolates.

In indirect ELISA, all four TuMV isolates, YC5, RC4, L, and $\mathrm{R}$, reacted positively with TuMV but weakly with KMV and DsMV antisera, including one purchased from Agdia (Table 1). In direct ELISA, they reacted strongly with TuMV antiserum but not with KMV or DsMV antiserum. In reciprocal tests, KMV and DsMV antigens did not react with TuMV antisera in both indirect and direct ELISA (Table 1). Prepared against bacterium-expressed coat protein (CP) antigen, the KMV antiserum reacted with its homologous antigen only in indirect but not in direct ELISA (Table 1). Unlike TuMV, KMV showed no serological relationship with DsMV in indirect or direct ELISA (Table 1).
Nucleotide sequences and molecular characterization. In reverse transcription (RT)-PCR using Potyvirus degenerate primers to react with purified virion RNAs and the total RNAs from YC5-, RC4-, TuMV-L-, and TuMV-R-infected tissues, the amplified DNA products were all 1.3 $\mathrm{kb}$ in size (Fig. 4). Cloning and sequencing showed that the amplified DNAs contained nucleotide sequences corresponding to the $3^{\prime}$ terminal region of potyvirus genome, including a part of the nuclear inclusion $b$ gene, a complete $\mathrm{CP}$ gene, and a $3^{\prime}$ noncoding region (NCR) followed by a poly-A tail. The nucleotide and deduced amino sequences of TuMV-L, TuMV-R, RC4, and YC5 have been filed with the GenBank and assigned the accession numbers AF530057, AF530056, AY134473, and AF530055, respectively. The percent identities between nucleotide and amino acid sequences of the CP genes and the $3^{\prime}$ NCRs of the four isolates were compared with other known potyviral sequences. The result showed that, except for TuMV isolates, none of the known potyviruses shared more than $90 \%$ nucleotide or amino acid identities in the regions with those of YC5 and RC4 (Table 2). Both YC5 and RC4 shared $95-99 \%$ identities in nucleotide and amino acid of $\mathrm{CP}$ gene and $3^{\prime}$

Table 2. Comparisons of nucleotide and amino acid identities of the coat protein (CP) genes and the 3 ' noncoding regions (NCRs) of Turnip mosaic virus (TuMV) isolates YC5 and RC4 obtained from calla lily with those of known potyvirus species

\begin{tabular}{|c|c|c|c|c|c|c|}
\hline \multirow[b]{3}{*}{ Potyvirus (Acc. no.) ${ }^{b}$} & \multicolumn{6}{|c|}{ Percent identity ${ }^{a}$} \\
\hline & \multicolumn{3}{|c|}{ YC5 } & \multicolumn{3}{|c|}{ RC4 } \\
\hline & CPnt & CP aa & $3^{\prime}$ NCR & CP nt & CP aa & $3^{\prime}$ NCR \\
\hline TuMV-YC5 (AF530055) & 100 & 100 & 100 & 97 & 99 & 98 \\
\hline TuMV-RC4 (AY134473) & 97 & 99 & 98 & 100 & 100 & 100 \\
\hline TuMV-L (AF530057) & 97 & 99 & 99 & 98 & 98 & 99 \\
\hline TuMV-R (AF530056) & 96 & 98 & 95 & 96 & 97 & 98 \\
\hline TuMV (D10927) & 96 & 98 & 99 & 97 & 98 & 99 \\
\hline TuMV (D83184) & 97 & 98 & 98 & 97 & 98 & 99 \\
\hline TuMV (AF169561) & 97 & 99 & 98 & 98 & 98 & 99 \\
\hline CTLV (AF203530) & 62 & 60 & 55 & 62 & 61 & 55 \\
\hline DsMV (AF048981) & 60 & 57 & 47 & 60 & 57 & 48 \\
\hline JYMV (AB027007) & 72 & 74 & 67 & 72 & 74 & 66 \\
\hline KMV (EMBL E12855) & 67 & 64 & 50 & 68 & 65 & 49 \\
\hline LMV (Z78227) & 68 & 64 & 47 & 68 & 65 & 46 \\
\hline LPV (AF511486) & 61 & 55 & 50 & 61 & 56 & 55 \\
\hline LyMMV (AF399672) & 67 & 59 & 50 & 66 & 59 & 49 \\
\hline TVBMV (AF274315) & 68 & 69 & 51 & 67 & 69 & 50 \\
\hline OMV (D00615) & 64 & 64 & 34 & 64 & 64 & 34 \\
\hline OYDV (AJ293278) & 65 & 63 & 48 & 66 & 64 & 47 \\
\hline PPV (X56258) & 57 & 58 & 52 & 57 & 57 & 50 \\
\hline PSbMV (D10453) & 67 & 64 & 60 & 67 & 64 & 60 \\
\hline PtVY (AF185965) & 65 & 64 & 49 & 65 & 64 & 48 \\
\hline ScMV (AJ316084) & 75 & 75 & 70 & 75 & 75 & 69 \\
\hline SPGV (Z83314) & 51 & 51 & 52 & 51 & 50 & 51 \\
\hline SYSV (AJ311370) & 66 & 51 & 63 & 66 & 50 & 63 \\
\hline TMMV (AF062926) & 63 & 59 & 57 & 63 & 60 & 56 \\
\hline WoYSV (AB000844) & 66 & 65 & 62 & 66 & 66 & 62 \\
\hline YMV (AJ244047) & 65 & 60 & 55 & 66 & 60 & 54 \\
\hline
\end{tabular}

a Percent identities of the respective nucleotide and amino acid sequences were analyzed by the program of Vector NTI Suite (InforMax, Inc., Wisconsin). Sequences of four TuMV isolates in this study were compared with those of three TuMV isolates and other potyviruses documented in the GenBank. The results of 19 sequences of different potyviruses with highest identities to TuMV-YC5 and TuMV-RC4 are listed in the table.

$\mathrm{b}$ The potyviruses listed are: CTLV (Carrot thin leaf virus), DsMV (Dasheen mosaic virus), JYMV (Japanese yam mosaic virus), KMV (Konjak mosaic virus), LMV (Lettuce mosaic virus), LPV (lycoris potyvirus), LyMMV (Lycoris mild mottle virus), OMV (Ornithogalum mosaic virus), OYDV (Onion yellow dwarf virus), PPV (Plum pox virus), PSbMV (Pea seedborne mosaic virus), PtVY (Pterostylis virus Y), ScMV (Scallion mosaic virus), SPGV (Sweet potato $G$ virus), SYSV (Shallot yellow stripe virus), TMMV (Tuberose mild mosaic virus), TVBMV (Tobacco vein banding mosaic virus), WoYSV (Welsh onion yellow stripe virus), YMV (Yam mosaic virus). 
NCR with TuMV-L, TuMV-R, and three other strains of TuMV selected from the GenBank. The results confirm serological data that YC5 and RC4 are strains of TuMV.

Detection of TuMV from imported calla lily. Calla lily plants do not originate in Taiwan. Their bulbs or tissue culture plantlets were imported from various countries, including New Zealand, Vietnam, Thailand, the Netherlands, and the United States. From 2001 to 2002, through the help of the governmental quarantine offices, a total of 132 imported calla lily bulbs were tested by ELISA and 11 bulbs were intercepted with positive TuMV infection. Of the 11 TuMV-infected bulbs, 3 were from Vietnam, while the other 8 came from the United States.

\section{DISCUSSION}

Based on the symptoms on cruciferous species, serological properties, and the nucleotide and amino acid sequences of $\mathrm{CP}$ genes and 3' NCR $(14,27,31)$, the two isolates YC5 and RC4 infecting calla lily were identified as strains of TuMV. TuMV is the most widespread virus in cruciferous crops (14). It also is reported to be naturally occurring in ornamental crops, lisianthus (10), and statice (22). To our knowledge, this is the first record that TuMV infects Zantedeschia spp.

TuMV may have been infecting calla lily for many years without being detected. This may be due to the serological crossreactivity between DsMV and TuMV as shown in this study. DsMV has been reported as the most prevalent and important virus infecting calla lily (29); therefore, most diagnostic labs might consider DsMV as the causal agent of calla lily specimens with systemic mosaic symptoms. When DsMV antisera were used in indirect ELISA for diagnosis, the positive ELISA readings might lead to the misidentification of TuMV as DsMV. This situation indicates the importance of cautious interpretation of serological data during virus identification.

As shown in this study, the two isolates of TuMV from radish and lisianthus also were capable of infecting calla lily and inducing yellow stripe and spot symptoms similar to those incited by YC5 and RC4. Our results suggest that the ability to infect calla lily is a common characteristic among TuMV strains. This is further supported by our observations that TuMV-infected plants frequently were found in calla lily fields adjacent to cabbage or radish (data not shown). Thus, the virus is disseminated from TuMV-infected cruciferous plants to calla lily plants by alate aphids. The occurrence of TuMV in calla lily in Taiwan probably is not a unique case. This can happen in any geographical areas where both calla lily and cruciferous crops are grown side by side. This may be the reason why TuMV was found in calla lily bulbs imported to Taiwan. TuMV induces severe systemic symptoms on calla lily. Its infection will jeopardize calla lily production. Appropriate measures to avoid or exclude TuMV from the mother stocks of calla lily should be implemented in countries where calla lily seedlings or bulbs are produced.

\section{ACKNOWLEDGMENTS}

We thank the Council of Agriculture, Executive Yuan, the Republic of China, Taiwan, for financial support; and H.-T. Hsu of the United States Department of Agriculture, Beltsville, MD for his careful review of this manuscript.

\section{LITERATURE CITED}

1. Chang, C. A. 1992. Characterization and comparison of passionfruit mottle virus, a newly recognized potyvirus, with passionfruit woodiness virus. Phytopathology 82:1358-1363.

2. Chang, C. A. 1993. Legume viruses in Taiwan. Plant Pathol. Bull. 2:149-160.

3. Chang, C. A., Chen, C. C., and Hsu, H. T. 2002. Partial characterization of two potyviruses associated with golden spider lily severe mosaic disease. Acta. Hortic. 568:127-134.

4. Chang, C. A., Chen, C. C., and Tsai, H. T. 1995. Characterization and purification of a virus isolate inducing lily mottling. Plant Prot. Bull. 37:446.

5. Chang, C. A., Chen, C. M., Chen, H. C., Deng, T. C., and Huang, C. H. 1989. Pea seed-borne mosaic virus causing pea mottling in Taiwan. Plant Prot. Bull. 31:366-376.

6. Chang, C. A., Hiebert, E., and Purcifull, D. E. 1988. Purification, characterization, and immunological analysis of nuclear inclusions induced by bean yellow mosaic and clover yellow vein potyviruses. Phytopathology 78:1266-1275.

7. Chang, C. A., and Lin, H. H. 1989. Passionfruit crinkle virus, a new potyvirus isolated from passionfruit in Taiwan. Plant Prot. Bull. 31:409-410.

8. Chang, C. A., Purcifull, D. E, and Zettler, F. W. 1990. Comparison of two strains of peanut stripe virus in Taiwan. Plant Dis. 74:593-596.

9. Chang, Y. C., Chen, Y. L., and Chung, F. C. 2001. Mosaic disease of calla lily caused by a new potyvirus in Taiwan. Plant Dis. 85:1289.

10. Chao, C. H., Chen, C. C., Chang, C. A., and Chen, C. C. 2000. Identification of a turnip mosaic virus isolate causing systemic yellow spotting on lisianthus. Plant Pathol. Bull. 9:115-122.

11. Chen, C. C., and Chang, C. A. 1998. Characterization of a potyvirus causing mild mosaic on tuberose. Plant Dis. 82:45-49.

12. Chen, C. C., Hsiang, T., Chiang, F. L., and Chang, C. A. 2002. Molecular characterization of Tuberose mild mosaic virus and preparation of its antiserum to the coat protein expressed in bacteria. Bot. Bull. Acad. Sin. (Taipei) 43:13-20.

13. Christie, S. R., Purcifull, D. E., Crawford, W. E., and Ahmed, N. A. 1987. Electron microscopy of negatively stained clarified viral concentrates obtained from small tissue samples with appendices on negative staining techniques. Fla. Agric. Exp. Stn. Tech. Bull. 872.

14. Edwardson, J. R., and Christie, R. G. 1991. The potyvirus group. Vol. I-IV: Fla. Agric. Exp. Stn. Monogr. 16.
15. Green, S. K., and Deng, T. C. 1985. Turnip mosaic virus strains in cruciferous hosts in Taiwan. Plant Dis. 69:28-31.

16. Holling, M., and Brunt, A. A. 1981. Potyvirus group. CMI/AAB Descriptions of Plant Viruses, No. 245.

17. Hu, W. C. 2001. Molecular characterization of Dasheen mosaic virus and Konjak mosaic virus infecting calla lily in Taiwan. Master thesis. Graduate Institute of Plant Pathology, National Taiwan University, Taipei, Taiwan.

18. Laemmli, U. K. 1970. Cleavage of structural proteins during the assembly of the head of bacteriophage T-4. Nature 227:680-685.

19. Li, R. H., Zettler, F. W., Purcifull, D. E., and Hiebert, E. 1998. The nucleotide sequence of the 3'-terminal region of dasheen mosaic virus (Caladium isolate) and expression of its coat protein in Escherichia coli for antiserum production. Arch. Virol. 143:2461-2469.

20. Pappu, S. S., Pappu, H. R., Chang, C. A., Culbreath, A. K., and Todd, J. W. 1998. Differentiation of biologically distinct peanut stripe potyvirus strains by a nucleotide polymorphismbased assay. Plant Dis. 82:1121-1125.

21. Pham, K., Langeveld, S. A., Lemmers, M. E. C., and Derks, A. F. L. M. 2002. Detection and identification of potyviruses in Zantedeschia. Acta. Hortic. 568:143-148.

22. Powell, C. C., and Lindquist, R. K. 1992. Viruses. Pages 133-142 in: Ball Pest and Disease Manual. Ball Publishing, Geneva, IL.

23. Provvidenti, R. 2002. Turnip mosaic potyvirus. Pages 1340-1343 in: Viruses of Plants. Descriptions and Lists from the VIDE database. A. Brunt, K. Crabtree, M. Dallwitz, A. Gibbs, and L. Watson, eds. CAB International, Oxon, UK

24. Purcifull, D. E., Adlerz, W. C., Simone, G. W, Hiebert, E., and Christie, S. R. 1984 Serological relationships and partial characterization of zucchini yellow mosaic virus isolated from squash in Florida. Plant Dis. 68:230-233.

25. Purcifull, D. E., and Batchelor, D. L. 1977. Immunodiffusion tests with sodium dodecyl sulfate (SDS)-treated plant viruses and plan viral inclusions. Fla. Agric. Exp. Stn. Tech. Bull. 788.

26. Purcifull, D. E, and Hiebert, E. 1979. Serological distinction of watermelon mosaic virus isolates. Phytopathology 69:112-116.

27. Shukla, D. D., Frenkel, M. J., and Ward. C. W. 1991. Structure and function of the potyvirus genome with special reference to the coat protein coding region. Can. J. Plant Pathol. 13:178-191.

28. Stace-Smith, R., and Tremaine, J. H. 1970. Purification and composition of potato virus Y. Phytopathology 60:1785-1789.

29. Ward, C. W., McKern, N. M., Frenkel, M. J., and Shukla. D. D. 1992. Sequence data as the major criterion for potyvirus classification. Arch Virol. Suppl. 5:283-297.

30. Zettler, F. W., Abo El-Nil, M. M., and Hartman, R. D. 1978. Dasheen mosaic virus. CMI/AAB Descriptions of Plant Viruses No. 191.

31. Zettler, F. W., and Hartman, R. D. 1987. Dasheen mosaic virus as a pathogen of cultivated aroids and control of the virus by tissue culture. Plant Dis. 71:958-963.

32. Zettler, F. W., and Hartman, R. D. 1995. Virus diseases of major ornamental crops-Dieffenbachia, Caladium, and Zantedeschia. Pages 464-470 in: Virus and Virus-like Diseases of Bulb and Flower Crops. G. Loebenstein, R. H. Lawson, and A. A. Brunt, eds. John Wiley \& Sons Inc., Chichester, UK. 